Стрельцов А. А.

Передача зашифрованных сообщений - вкраплений в художественном тексте с английского языка на русский

Южный федеральный университет, ул. Б. Садовая, 105/42, г. Ростов-на-Дону, 344006, Россия

E-mail:al-astr@yandex.ru

ORCID iD: 0000-0002-7882-0495

Статья поступила 26 июля 2021 г.; принята 27 сентября 2021 г.; опубликована 30 сентября 20212.

\begin{abstract}
Аннотация. В статье рассматриваются случаи, когда переводчики сталкиваются с сообщениями, смысл которых скрыт при помощи простого шифра. На примере художественных произведений британских (Артур Конан Дойль, Агата Кристи) и американских (Эдгар По, Дэн Браун) писателей показано, как отечественные переводчики преодолевали возникшие трудности. Для сокрытия информации могут использоваться шифры подстановки («Золотой жук», «Пляшущие человечки»), анаграммы («Код да Винчи»), «пустышечный» шифр («Глория Скотт»), а также стеганография («Четверо подозреваемых»). В первых трех случаях представлены по два примера с переводом. Переводчику необходимо не только показать процесс дешифровки, но и по возможности передать закодированный характер сообщения средствами русского языка. Установлено, что примерно в половине случаев имеет место перевод расшифрованного сообщения. Выбор такого «простого» способа обусловлен тем, что переводчику в этом случае не требуется создавать русскоязычный аналог зашифрованного текста. При этом остается нереализованной сверхзадача перевода - адекватной передачи изначального авторского замысла. Там, где имеется несколько вариантов перевода на русский язык (5 дореволюционных и 1 советский перевод новеллы «Золотой жук», 9 переводов рассказа «Четверо подозреваемых», большая часть из которых выполнена в 1990-х гг.), приводится краткий переводческий анализ. Установлено, что даже если переводы выполнены в один исторический период, между ними могут быть существенные отличия в передаче не только второстепенных, но и важных единиц перевода, а в отдельных случаях отмечались негрубые переводческие ошибки.
\end{abstract}

Ключевые слова: Криптограмма; Шифротекст; Анаграмма; Расшифровка; Перевод

Информация для цитирования: Стрельцов А. А. Передача зашифрованных сообщений - вкраплений в художественном тексте с английского языка на русский // Научный результат. Вопросы теоретической и прикладной лингвистики. 2021. T.7, N3. C. 56-71. DOI: 10.18413/2313-8912-2021-7-3-0-5 
DOI: 10.18413/2313-8912-2021-7-3-0-5

\title{
Alexis A. Streltsov (D) Reproduction of encrypted messages in fiction from English into Russian
}

\author{
Southern Federal University, \\ 105/42 B. Sadovaya St., Rostov-on-Don, 344006, Russia \\ E-mail: al-astr@yandex.ru \\ ORCID iD: 0000-0002-7882-0495
}

Received 26 July 2021; accepted 27 September 2021; published 30 September 2021

\begin{abstract}
This article examines cases where translators are confronted with messages whose meaning is obscured by a simple cipher. Russian translators had to overcome certain difficulties while translating certain passages in the works of British (Sir Arthur Conan Doyle, Agatha Christie) and American (Edgar Allan Poe, Dan Brown) fiction writers. Substitution code ("The Gold-Bug", "The Adventure of the Dancing Men"), anagrams ("The da Vinci Code"), as well as different kinds of text steganography ("The Gloria Scott", "The Four Suspects") can be used to encrypt the information. Each case is illustrated with two examples. The translator has to depict not only the very process of deciphering a message, but also render its cryptic nature with the means of a target language (Russian). We show, that in half of the cases it is a mere translation of the deciphered text. It is a simpler way, because there is no need to create an analogue thereof. The grand purpose, however, remains unachieved. In two instances there were multiple translations of the same text (6 of "The Gold-Bug" by E.A Poe and 9 of "The Four Suspects" by A. Christie). This phenomenon can be explained not only by the popularity of the stories, but by the relatively small circulation of certain editions. We have undertaken a comparative analysis of these translations and have revealed discrepancies, concerning more and less significant translation units and, in some cases minor errors.
\end{abstract}

Keywords: Cryptogram; Cipher text; Anagram; Decoding; Translation

How to cite: Streltsov A. A. (2021). Reproduction of encrypted messages in fiction from English into Russian. Research Result. Theoretical and Applied Linguistics, V.7 (3), 56-71, DOI: 10.18413/2313-8912-2021-7-3-0-5

\section{ВВЕДЕНИЕ (INTRODUCTION)}

В определенном смысле работу переводчика можно уподобить работе дешифровщика: и тот и другой работают с текстом, понятным составителю, и делают его доступным получателю; в обоих случаях автор текста не знает заранее, кто его прочтет (авторы многих книг и статей изначально не рассчитывают, что их произведения будут переведены на другие языки; шифровка может быть перехвачена). Различие в том, что зашифрованные тексты представляют собой примеры «вторичных кодов»: в отличие от первичного, который «разворачивается линейно, например, как записанный текст или услышанная речь», так что для его (первичного текста - A.C.) понимания «реципиенту не требуется прилагать дополнительных усилий», поскольку «правила интерпретации этого кода (в нашем случае языка) закладываются в процессе обучения языку», «вторичный код требует определенных знаний, поскольку в сообщении имеется скрытый смысл ... [и] предполагает ограничение потенциального количества адресатов сообщения» (Культурные трансферы, 
2015: 123-125). Зашифрованные тексты изначально ориентированы на очень узкий круг лиц, тогда как художественные и, публицистические и, в меньшей степени, научные и официально-деловые тексты на широкую аудиторию. Нужно также отметить, что обычно переводчик передаёт некоторое оригинальное сообщение, написанное на одном языке на другой язык (язык перевода), тогда как шифрование это особая форма записи сообщения на каком-либо одном языке, требующая воссоздания её прагматического потенциала в языке перевода средствами, отличными от исходного кода шифрования. Иногда возникают особые случаи, когда в тексте для перевода представлены не только разножанровые фрагменты, но и некие скрытые послания.

\section{OCHОВНАЯ ЧАСТЬ (MAIN PART)}

\section{Цель работы}

Целью нашей работы является анализ способов передачи зашифрованных сообщений, содержащихся в англоязычных художественных произведениях, на русский язык. Их наличие усложняет задачу переводчика: необходимо не только перевести, но и сделать это таким образом, чтобы в наибольшей степени сохранить замысел автора; также неясно, допустимо ли создание вторичного шифротекста.

Одновременно нам предстоит проверить утверждение, что «все известные шифры восходят к двум разновидностям: шифрам замены и шифрам перестановки» (Там же: с. 129); первые требуют знания ключа при сохранении линейного характера правил интерпретации, а в случае с последними линейный характер меняется на нелинейный. Научная новизна работы заключается в том, что впервые в истории отечественного и, возможно, зарубежного природоведения - не удалось установить наличие других публикаций по этой теме, нами разрабатывается проблема передачи закодированных сообщений в текстах художественной литературы, притом, что большая часть проанализированных нами произведений переводилась неоднократно. В имеющихся зарубежных публикациях исследователи обращают внимание исключительно на медикопсихологические (Vucinic, 2010), (Giammarco, 2013), (Dean, 2020) или историко-литературные (Raffensperger, 2010), (Fariña-Pérez, 2012), (Llorente, 2021) аспекты в жизни авторов детективов или их персонажей, а не на переводческие.

\section{Материалы исследования}

Материалом первой части исследования послужили два англоязычных произведения, опубликованные по обе стороны Атлантики с разницей примерно в 60 лет: новелла американского писателя и поэта Эдгара Аллана По «Золотой жук» (Edgar Allan Poe «The GoldBug») и рассказ английского писателя сэра Артура Конан Дойля «Пляшущие человечки» (Sir Arthur Ignatius Conan Doyle «(The Adventure Of) The Dancing Men»).

Общим в обоих криптограммах (шифротекстах) является то, что они являлись сравнительно простыми подстановочными (шифр замены), что подразумевает всего лишь «изменение знаков при сохранении правил интерпретации» (Культурные трансферы, 2015: 123) и это позволило применить (Уильяму Леграну и Шерлоку Холмсу, соответственно) в обоих случаях частотный анализ текста. Имелись и различия: Легран изначально имел весь текст, который был не поврежден, тогда как Холмсу пришлось ждать, пока у него не скопится достаточный для анализа объем сообщений. С другой стороны, в первом случае текст был написан скрытыми чернилами (для прочтения которого следовало осторожно промыть кусочек пергамента и прогреть его), и язык был неясен. Холмс мог заранее предположить, что послания были на английском языке, но внешне они выглядели как детские рисунки. Также нужно учесть, что в первом случае текст 
отдавали предпочтение генерализации «дом» (правда, современник автора счел, что «замок» больше подходит для епископа), тогда как в советское время предпочтение было отдано устаревшему соответствию «трактир» (а в переводе 1858 г. - основному соответствию иностранному слову «отель», тогда как четверть века спустя переводчик воспользовался русскоязычным соответствием - словом «гостиница»); в двух переводах, сделанных в прошлом веке, при переводе существительного «bishop» в форме притяжательного падежа также использовано существительное «епископ» (бискуп - ycmap. «епископ в неправославной церкви») в родительном падеже и осуществлена перестановка, в переводах 1848 и 1874 гг. применена частиречная замена - «епископский». Чередование предлогов «на/в стуле» является малосущественным: Н.В. Щелгунов перевел буквально, но без потери смысла. Есть различия в передаче направления: «северо-восток к северу/на север» в дореволюционных переводах, и «север-северо-восток» в последнем по времени переводе, что можно объяснить изменившимися правилами чтения показаний компаса. Слова «branch» и «limb» в переводах XX в. переданы соответствиями «ветвь/сук» (с чередованием, хотя иерархия четко не прослеживается), хотя по смыслу правильнее «ствол» (есть словосочетание «главный ствол дерева»; как, впрочем, и «главный сук «сук/ветвь/ветка» соответственно - именно ему отдавали предпочтение переводчики XIX века. Фраза «shoot from the left eye ... a bee line» А. Старцевым и К.Д. Бальмонтом переведено почти буквально как «стреляй из левого глаза/сквозь левый глаз... прямая/по прямой линии», тогда как вариант «спустите/опусти(те) из левого глаза ... прямую линию» в данном контексте выглядит предпочтительнее (ср. «опустите перпендикуляр»). Перевод последней части текста «through the shot fifty feet out» у Н.В. Шелгунова и А. Старцева - почти дословный: «through» - «ч(e)peз», «shot» передано вариативным соответствием «пуля/выстрел», расстояние - калькированием, тогда как К.Д. Бальмонт переводит «shot» почему-то как «навылет»; с другой стороны, Щелгунов опустил при переводе словосочетание «from the tree» «от дерева».

В целом, перевод проанализированного отрывка, выполненный А. Старцевым, представляется нам предпочтительным. Обращает на себя внимание в первую очередь то, что в оригинальном шифротексте из «Золотого жука» 203 знака, в расшифрованном - 209, в переводе А. Старцева (и анонимном переводе 1858 г.) - 211, К.Д. Бальмонта - 212, И.Д. Городецкого - 219, Н.В. Шелгунова 204; все - без учета пробелов (а дореволюционные переводы - в современной орфографии). Переводы, выполненные в XX веке, близки по числу знаков к оригинальной расшифровке текста, но Н.В. Шелгунов смог представить перевод, «количественно» почти совпадающий с оригинальным шифротекстом. Также необходимо отметить, что переводчики не пытались «подгонять» свой перевод под оригинальный шифротекст, что было бы невозможно вследствие большой разницы между английским и русским языками: переводу подвергался сам процесс расшифровки и его результат, и переводчику не нужно ничего додумывать самому.

Анализ перевода зашифрованных сообщений из рассказа А. К. Дойля «Пляшущие человечки»

Другим путем пошли Мария и Николай Чуковские, создавшие единственный известный нам русскоязычный перевод «Пляшущих человечков»: в оригинальном тексте (Doyle, 1997: 12) 62 рисунка, а в переводном (Дойль, 1981) - 67. Ниже представлено послание на английском и русском языках с расшифровкой: 

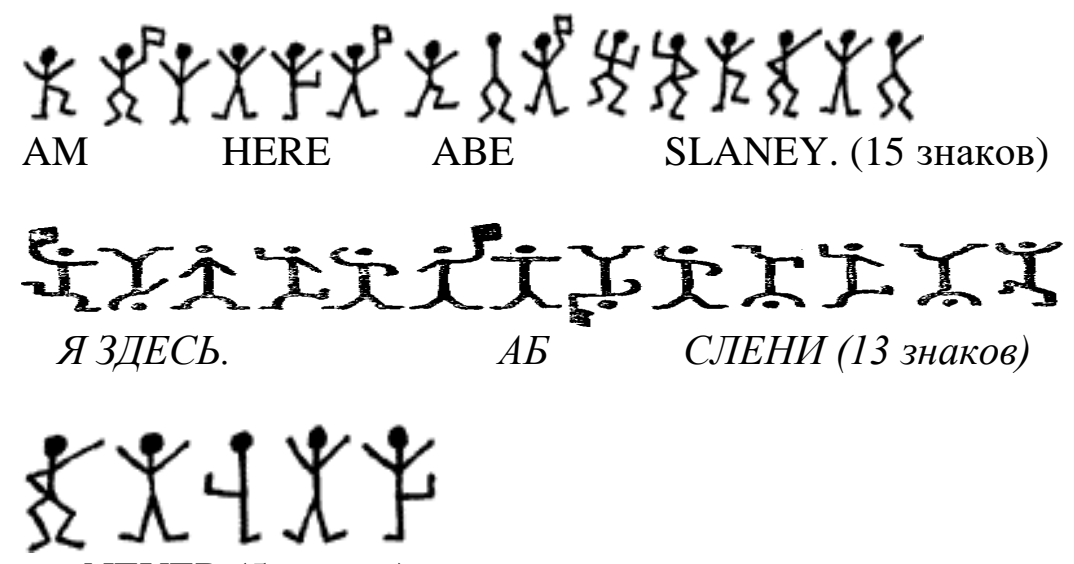

NEVER (5 знаков)

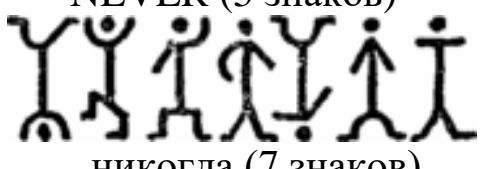

никогда (7 знаков)
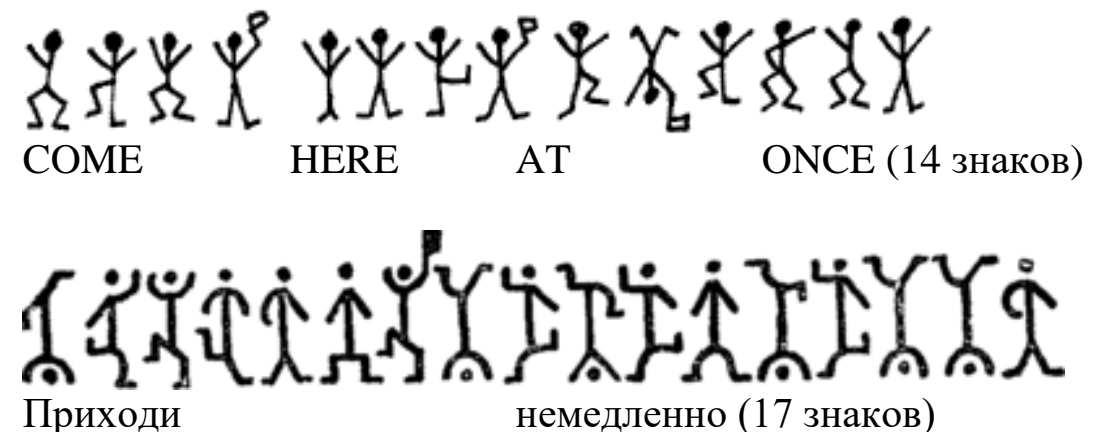

Приходи

немедленно (17 знаков)

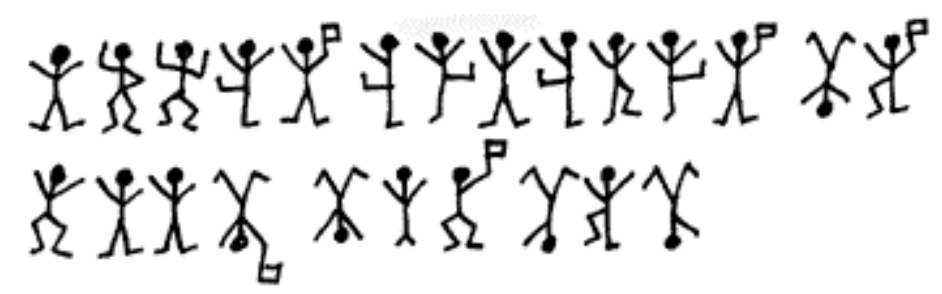

ELSIE PREPARE TO MEET THY GOD (24 знака)

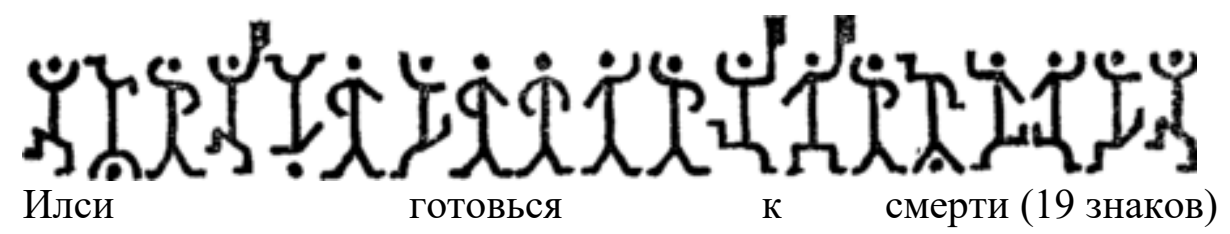

Несложно заметить, что в последнем случае вторая половина послания переведена не дословно: возможно, фраза «предстать перед Господом» показалась слишком длинной, а «К встрече с Господом» - немногим короче, но несколько двусмысленна; к тому же в обоих вариантах упоминается Бог (что, без

особой необходимости,

было нежелательно в советское время).

Переводчикам пришлось адаптировать шифр под особенности русского языка: в кириллице больше букв, чем в латинице, и, даже при том, что в этих посланиях использовались не все буквы алфавитов, в переводе получилось 23 знака 
вместо 16 в оригинале. (В статье (Особенности перевода..., 2020), название которой близко к теме нашей статьи, разбирается не перевод, а дается анализ способа расшифровки).

\section{Особенности передачи анаграмм}

Более простым, на первый взгляд, способом скрыть смысл послания является перестановка букв: «Нескладное тайное послание - это всегда анаграмма» (A secret message this awkwardly worded is always an anagram), как отмечала мультипликационный персонаж Лиза Симпсон в серии «Gone Maggie Gone». Под анаграммой понимается «слово, словосочетание, полученное в результате перестановки букв» (Жеребило, 2010: 29).

Самая известная анаграмма в современной художественной литературе приводится в романе Дэна Брауна «Код да Винчи»:

\section{3-3-2-21-1-1-8-5}

O, Draconian devil!

Oh, lame saint! (Brown, 2003: 93)

Перевод бессмысленного послания также не будет иметь смысла, и поэтому переводчик Наталья Вениаминовна Рейн создала новое: «На вид идола родич! О мина зла!» (Браун, 2004: 188). Если воспользоваться ключом, представленным выше, можно получить «Leonardo da Vinci» и «The Mona Lisa», которым в русском языке соответствуют (почти побуквенно) - «Л(е)онардо да Винчи» и «Мона Лиза». Это преобразование позволяет полностью достичь цели послания, - привлечь внимание к конкретному произведению определенного художника. Такой способ труден, и поэтому название другой картины, - «Les Demoiselles d'Avignon» Пабло Пикассо, также послужившей в этом же романе основой для анаграммы (vile meaningless doodles), но не имевшей значения для развития повествования, Н.В. Рейн не перевела, а имплантировала в текст, дав соответствующую сноску (переводческий комментарий).
Здесь мы считаем необходимым сделать небольшое отступление, чтобы охарактеризовать перевод другой известной «книжной» анаграммы. В романе Дж. Роулинг «Гарри Поттер и Тайная Комнате» выясняется, что имя главного злодея - анаграмма: «Tom Marvolo Riddle $\rightarrow$ I am Lord Voldemort». Сохранить ее полностью в переводе на русский язык невозможно, и поэтому М. Литвинова предложила вариант «Том Нарволо Реддл $\rightarrow$ Лорд Волан-де-Морт», вольно или невольно создав аллюзию почти также звали одного из главных героев романа М. Булгакова «Мастер и Маргарита».

В переводе М. Спивак «Том Ярволо Реддль $\rightarrow$ Я Лорд Вольдеморт» анаграмма полностью повторяет оригинал, за исключением того, что добавлен мягкий знак. Правда, в обоих случаях меняется первая (или первая и вторая) буква в имени его дедушки. В одном из «фанатских» переводов изменена только вторая буква в имени дедушки (Том Мерволо Риддл $\rightarrow$ Имя - Лорд Волдеморт) зато сохранена оригинальная фамилия Риддл. Правда, сама анаграмма претерпела изменения. Сообщество фанатов «Potter's Army» предпочло ничего не переделывать, - они просто написали имена на русском, а рядом - оригинальное написание (Анаграмма Волдеморта..., 2015).

Иначе действовали переводчики одной из серий 20-го сезона «Симпсонов»(Gone Maggie Gone, 2009). Предложение «Great crimes kill holy sage», оказавшееся анаграммой, просто перевели: «Ужасные преступления убивают святого мудреца». Также поступили и с двумя вариантами расшифровки: «Regally, the rock gem is Lisa» («По-царски, драгоценный камень это Лиза») и «It's really Maggie, Sherlock» («На самом деле это Мэгги, Шерлок»). Во всех случаях переводы довольно точные, почти дословные, но не имеют отношения к расшифровке анаграммы. 


\section{Особенности перевода сообщений, содержащих лишние слова}

В той же серии (Gone, Maggie, Gone, 2009) приводится пример еще одного способа сокрытия послания, известного как «пустышечный шифр»: «One Turn More Around Time Seek Your Springfield's Hopeless Biggest Try Man Again Made Numb Ring Skull» (Gone, Maggie, gone, 2009). Если читать слова через одно, получатся два сообщения, одно издевательское: «One more time. Your hopeless. Try again, numbskull», а другое верное: «Turn around. Seek Springfield's biggest man(-)made ring» («Обернись, найди в Спрингфилде самое большое рукотворное кольцо»); оба они были переведены почти дословно.

Тот же прием использовался в рассказе Артура Конан Дойла «Глория Скотт». В оригинале в записке было написано: «The supply of game for London is going steadily up. Head-keeper Hudson, we believe, has been now told to receive all orders for fly-paper and for preservation of your hen-pheasant's life» (Doyle, 2020: 11). $\mathrm{B}$ переводе Г. Любимовой: «С дичью дело, мы полагаем, закончено. Глава предприятия Хадсон, по сведениям, рассказал о мухобойках все. Фазаньих курочек берегитесь» (Дойль, 1990: 375).

Хотя перевод сложного слова «старший лесник» (head-keeper) как «глава предприятия», и замена «мухоловок» (flypaper) на «мухобойки», а «самок фазана» на «фазаньих курочек» представляются нам ошибочными, в целом переводчик справился с поставленной задачей - будучи прочитанной через два слова, записка должна была приобрести зловещий смысл: «The game is up. Hudson has told all. Fly for your life» («Дело закончено. Хадсон рассказал все. Берегитесь»). Такой прием известен как «пустышечный шифр».
Анализ
переводов
рассказа

\section{А. Кристи «Четверо подозреваемых»}
Разновидностью пустышечного шифра является прием, который был

использован в одном из коротких рассказов Агаты Кристи (Agatha Christie) "The Four Suspects", который на русский язык переводили по-разному.

Ниже представлены оригинал и переводы письма, содержавшего скрытое послание:

My Dear Rosen,

Just back from Dr. Helmuth Spath's. I saw Edgar Jackson the other day. He and Amos Perry have just come back from Tsingtau. In all Honesty I can't say I envy them the trip. Let me have news of you soon. As I said before: Beware of a certain person.

You know who I mean, though you don't agree.

Yours, Georgina (Christie, 2016: 154)

«Цветы смерти», перевод А. Шарова,

В. Постникова:

«Мой дорогой Розен!

Только что вернулась от доктора Ульриха Шпата. На днях видела Брайана Джексона. Они с Енохом Перри только что вернулись из Египта в Йорк. Не сказала бы, что завидую их поездке. Как я уже говорила, берегись одного человека, ты знаешь кого, хоть и не согласен со мной».

Твоя Георгина (Кристи, 1990: 448) «Четверо подозреваемых», перевод

И. Борисова:

«Дорогой Розен,

Я сейчас от Самюэля Спата, а на днях видела Майкла Боумена. Он и Елизавета Джексон только что вернулись из Гангуна. Откровенно говоря, поездка была не слишком удачной, но это уже, можно сказать, Традиция. Поскорее пришлите о себе весточку. Еще раз прошу: остерегайтесь того человека. Вы знаете, о ком я... Напрасно вы мне не верите».

Ваша Георгина (Кристи, 2000: 575) «Четверо подозреваемых», перевод

В. Ноздриной: «Дорогой доктор Розен!

Я только что от доктора Ральфа Спэта. На вечеринке была Ева Джексон, она рассказывала доктору Вильямсу (я: много докторов!) о своем путешествии по восточному побережью Китая. Амос 
Перри сказал. Что непременно проделает тот же путь, - так красочно было ее повествование. С надеждой жду от вас весточку. Остерегайтесь одного человека того, о ком говорил Шон Уэтерби».

Ваша Георгина (Кристи, 1992: 335)

«Четверо подозреваемых», перевод В. Кузьмичева:

Дорогой Розен, на днях, после моего возвращения от Хелмута Спата, виделись с Эдгаром Джексоном. Он и Амос Перри только что возвратились из Тсинтау.

Сказать по Чести, я не завидую их поездке. Надеюсь, что в скором времени Вы сообщите о себе. Как было сказано, остерегайтесь одного человека. Вы знаете, кого я имею в виду, хотя и не согласны со мной».

Ваша Джорджина (Кристи, 1996: 435)

«Четверо подозреваемых», перевод

\section{В. Николаева:}

«Я только что от Спета. Вчера же мы виделись с Тедом Джексоном. И он, и Амос Перри приняты мною с большим Радушием после их возвращения из ТингТау. Сообщите, какие у вас новости. Опасайтесь известного вам лица, хотя здесь вы, конечно, со мной не согласитесь».

С наилучшими пожеланиями, Георгина (Кристи, 1991: 338)

«Четверо под подозрением», перевод Л. Девель, В. Потенко:

«Мой дорогой Розен!

Только что от Хелмута Спата. На днях виделись с Эдгаром Джексоном. Он и Амос Перри недавно вернулись из Тсинтау, но Честность не позволяет мне сказать, что я завидую их поездке. Дайте знать о себе в ближайшее время. Как говорилось ранее, остерегайтесь одного человека.

Вы знаете, кого я имею в виду, хотя вы и не согласны».

Ваша Георгина (Кристи, 1990: 464)

«Подозреваются все», перевод

В. Тимашева:

«Мой dear Розен! Недавно была у доктора Гельмута Спата. Виделась с Edgar Джексоном. Он и Amos Перри только что возвратились из Tsingtan. In all my honesty, я не могу сказать, что завидую их поездке. Жду от вас скорых вестей. Как я говорила раньше, остерегайтесь этого человека. Вы знаете, кого я имею в виду, хотя и не согласны со мной».

Ваша Георгина (Кристи, 1991: 324)

«Четверо подозреваемых», перевод

В. Михалюка:

«Дорогой Розен, только что была у доктора Спата. На днях видела Маркуса Джексона. Он и Елизавета Перри недавно вернулись из Рабата. Скажу честно: я ни капли не завидую им - такие путешествия приводят меня в Трепет. Надеюсь скоро получить от вас весточку. Напоминаю: хоть вы и не верите мне, все же остерегайтесь того человека, о котором я говорила».

Ваша Георгина (Кристи, 2012: 549) «Четверо подозреваемых», перевод

3. Красневской:

«Мой дорогой Розен, на днях виделась с Умберто Рози. Они вместе с Майклом Перри недавно вернулись из Рабата. Говорю без Искры сомнения: ничего интересного в их путешествии не было. Дай мне знать о себе в ближайшее время. Как я уже говорила, остерегайся одной особы. Ты догадываешься, о ком я, хотя, знаю, по-прежнему не согласен со мной.

Твоя Джорджина» (Кристи, 2016)

Указанием на то, что это - не простое письмо, стало написанное с заглавной буквы нарицательное существительное «Honesty», в переводах - «Традиция», «Честь», «Честность», «Надежда», «Радушие», «Трепет» и «Искра». Перечень имен собственных ничего не скажет обычному человеку, но сразу обратит на себя внимание цветовода:

"Dr. Helmuth Spath". Pure lilac, a wonderfully fine flower, carried on exceptionally long and stiff stem. Splendid for cutting and garden decoration. A novelty of striking beauty. 
"Edgar Jackson". Beautifully shaped chrysanthemum-like flower of a distinct brick-red colour.

"Amos Perry". Brilliant red, highly decorative.

"Tsingtau". Brilliant orange-red, showy garden plant and lasting cut flower.

"Honesty". Rose and white shades, enormous perfect shaped flower (Christie, 2016: 158).

«Цветы смерти», перевод А. Шарова,

\section{В Постникова:}

«Ульрих Шпат. Чистая линия. Удивительно красивый цветок на длинном прочном стебле. Замечательно украшает сад и хорошо срезается.

Брайан Джексон. Похожий на хризантему цветок краснокирпичного цвета.

Енох Перри. Блестящий красный, очень декоративный.

Йорк - знаменитый долго цветущий оранжево-красный тюльпан» (Кристи, 1990: 450).

«Четверо подозреваемых», перевод

И. Борисова:

«Самюель Спат... Удивительно изящный цветок с бледно-сиреневыми лепестками и исключительно длинным и крепким стеблем. Одинаково хорош для клумбы и для букета.

Майкл Боумен... Немного напоминающий хризантему, удивительно изысканный цветок яркого, кирпичнокрасного окраса.

Елизавета Джексон... Ярко-красное, необычайно декоративное растение.

Рангун... Яркий и эффектный декоративный цветок насыщенного оранжевого цвета, долго сохраняется в срезанном виде.

Традиция... Крупный цветок прекрасной формы с розовато-белыми лепестками» (Кристи, 2020: 578).

«Четверо подозреваемых», перевод

В. Ноздриной:

«Ральф Спэт. Чисто сиреневые без примесей, удивительно нежные цветы на длинных и твердых стеблях. Прекрасно поддаются подрезанию и служат к украшению сада.

Ева Джексон. Прекрасно очерченные, похожие на хризантемы цветы ярко выраженного кирпично-красного оттенка.

Доктор Вильямс. Розовые и белые тона. Огромные, идеальной формы цветы.

Амос Перри. Сверкающие оранжевокрасные цветы, долго сохраняющие свежесть.

Надежда - ярко красные, в высшей степени декоративные...

Шон Уэтерби. Восхитительная новинка...» (Кристи, 1992: 339)

«Четверо подозреваемых», перевод

В. Кузьмичева:

«Доктор Хелмут Спат. Чистый сиреневый цвет, удивительно изящный цветок на очень длинном и крепком стебле. Хорош для срезки и для украшения сада. Новинка изумительной красоты.

Эдгар Джексон. Красивый, сходный по форме с хризантемой, отчетливо выраженного красно-кирпичного цвета.

Амос Перри. Ярко-красный, в высшей степени декоративен.

Тсинтау. Яркий оранжево-красный, эффектный садовый цветок; будучи срезанным, долго сохраняется.

Честь. Розового и белого оттенков, крупный цветок превосходной формы» (Кристи, 1996: 440-441).

«Четверо подозреваемых», перевод

В. Николаева:

««Спет». Сиреневый цветок на исключительно длинном и негнущимся стебле. Поражает своим прекрасным внешним видом и способен украсить любой сад.

«Тэд Джексон». Кирпично-красный цветок, по форме несколько напоминающий хризантему.

«Амос Перри». Ярко-красный цветок эффектного вида.

«Радушие». Розового или белого цвета, очень больших размеров.

«Тинг-Тау». Темно-оранжевый цветок на прочном стебле» (Кристи, 1991: $342)$. 
«Четверо под подозрением», перевод Л. Девель, В. Потенко:

«Доктор Хелмут Спат. Чистосиреневый, удивительно изящный цветок с исключительно длинным и крепким стеблем. Хорош для срезки и для украшения сада.

Эдгар Джексон. Красивый хризантемовидной формы цветок четко выраженного красно-кирпичного цвета.

Амос Перри. Ярко-красный, чрезвычайно декоративен.

Тсинтау. Яркий оранжево-красный, эффектный декоративный садовый цветок, долго сохраняется в срезанном виде.

Честность. Розовых и белых оттенков, крупный цветок прекрасной формы» (Кристи, 1990: 468).

«Подозреваются все», перевод

В. Тимашева:

«D.-r. Гельмут Спат. Великолепная (беспримесная) сирень, изумительной красоты цветки. Высылаются длинные и крепкие черенки. Прекрасно подходит для украшения сада и требует малого ухода за собой. В этом сорте сирени скрыта особая прелесть ...

Edgar Джексон. Хризантемы чудесной формы, бордового цвета...

Amos Перри. Густой красный цвет, очень красивы...

Tsingtau. Эффективное садовое растение оранжево-красного цвета...

Honesty. Цветок классической формы розовато-белового цвета...»

(Кристи, 1991: 328)

«Четверо подозреваемых», перевод

\section{В. Михалюка:}

«Доктор Спат. Чистые сиреневые лепестки, на редкость красивый цветок с очень длинным и крепким стеблем. Прекрасно подходит для украшения сада и хорошо срезается. Один из лучших экземпляров своего вида.

Маркус Джексон. Прекрасной формы цветок, немного напоминающий хризантему, необычного кирпичного цвета.

Елизавета Перри. Ярко-красный декоративный цветок.
Рабат. Яркий, оранжевый с красным оттенком цветок. Прекрасное садовое растение и долго сохраняется в срезанном виде.

Трепет. Розовые и белые оттенки, очень большой цветок прекрасной формы». (Кристи, 2012: 554-555)

«Четверо подозреваемых», перевод

3. Красневской:

««Умберто Рози». Сирень сортовая, изумительной красоты гроздья на очень длинных и твердых стеблях. В равной степени годится и для букетов, и для украшения сада. Замечательная новинка.

«Майкл Перри». Красивые цветы красно-коричневого цвета, по форме похожие на хризантемы.

«Рабат». Декоративное садовое растение с яркими цветами оранжевокрасного цвета, цветы долго сохраняются в срезанном виде.

«Искра»... Крупные цветы очень красивой формы, цветет розовым и белым» (Кристи, 2016).

Указание на «цветочный» характер шифра содержалось и в подписи: письмо пришло из Германии, а по-немецки die Georgine переводится как «георгин»; на языке цветов он означает «предательство и обман» ("Treachery and Misrepresentation") (в переводе В. Николаева «безоговорочное осуждение за предательство», а у В. Ноздриной «коварную измену») - адресат письма содействовал уничтожению некоего тайного общества и его члены, оставшиеся на свободе, послали своего рода «черную метку» своему разоблачителю, скрывавшемуся в глуши Сомерсета и полагавшему, что до него не доберутся.

Само письмо представляется собой форму классической стеганографии, когда послание выглядит как обычный текст. Использованный в данном случае шифр близок к акростиху: если взять первые буквы названий сортов декоративных цветов, то получится в оригинале «Death», а в переводах - «Убей», «Умри» и «Смерт(ь)» (А в переводе В. Николаева и 
В. Ноздриной, почему-то, «Старт» и «Реванш», что не соответствует цели сообщения). Поскольку в оригинальном тексте зашифрованное слово состоит из пяти букв, А. Шаров и В Постников, и 3. Красневская вынуждены были прибегнуть к опущению одной из значимых единиц, что в данном случае было оправдано.

Также следует отметить вариативность в передаче имен собственных: Хелмут/Гельмут, Шпат/Спат/Спэт/Спет, Георгина/Джорджина. В некоторых случаях переводчики прибегали к замене имени, если это было оправдано выбранным ими способом передачи зашифрованного послания, Ульрих/Ральф/Самюэль (в оригинале Хелмут) Спат, Брайан/Маркус/Ева/Елизавета/Тед (в оригинале Эдгар) Джексон, Енох/Майкл/Елизавета (в оригинале - Амос) Перри; единственный топоним - Тсинтау - заменяли на Йорк, Гангун (правильно «Рангун», но в самом письме допущена опечатка) и Рабат. В. Ноздрина прибегла к генерализации «восточный Китай», и ввела новые имена: Вильям (доктор, как и Розен и, почему-то, Спэт) и Шон Уэтерби. Сравнивая отдельные переводы, можно предположить, что перевод В. Кузьмичева был выполнен под влиянием перевода Л. Девель.

Можно также обратить внимание на то, что существительное "lilac" иногда переводится прилагательным «сиреневый», a "brick-red" в половине случаев калькируется, а в остальных подвергается разного рода заменам: «кирпичный», «красно-коричневый», «бордовый».

$\mathrm{He}$ все решения можно признать удачными: переводчик Л. Девель не стал вносить изменений, в результате чего названия сортов были переданы точно, но цель сообщения не была достигнута, а В. Тимашев прибег к межъязыковому переносу, в результате чего в тексте появились иноязычные вкрапления. Также нужно отметить, что переводчики, озаглавившие текст «Цветы смерти», не только вольно (слишком образно, или по аналогии со сборником стихов Шарля Бодлера) отнеслись к авторскому названию, но и вложили в зашифрованное послание другой смысл, - адресат сам должен был стать жертвой.

\section{ЗАКЛЮЧЕНИЕ (CONCLUSIONS)}

Нами были проанализированы 6 переводов новеллы Э.А. По «Золотой жук» XIX и XX веков, единичные переводы рассказов А.К. Дойля и 9 переводов рассказа А. Кристи «Четверо подозреваемых», выполненных на рубеже XX и XXI веков. Такое большое количество переводов обеспечило репрезентативность выборки. Сопоставительный анализ переводов текстов художественной литературы, содержащих зашифрованные сообщения, проведён впервые.

В ходе исследования нам встречались лишь элементарные, или же буквенные коды - шифры замены и перестановки (в частности, анаграммы). Пересоздание зашифрованного текста является предпочтительным способом его передачи на другой язык, но в силу сопряженных с ним сложностей в большинстве случаев предпочтение отдается его переводу с использованием контекстуальных замен. Для подтверждения результатов исследования представляется возможным проанализировать перевод зашифрованных сообщений на примере других пар языков.

\section{Список литературы}

Анаграмма Волдеморта в русских переводах, $2015 . \quad$ URL: https://diary.ru/ d88/p204183439_anagramm a-voldemorta-v-russkih-perevodah.htm (дата обращения: 01.10.2020).

Браун Д. Код да Винчи / пер. H.В. Рейн. М.: АCT, 2004. 447 c. URL: https://www.litmir.me/br/?b=47079\&p=1 (дата обращения: 02.05.2020).

Дойль А.К. Пляшущие человечки / пер. М. и Н. Чуковских. М.: 
Машиностроение, 1981. С. 291-315. URL: http://lib.ru/AKONANDOJL/sh_dancm.txt (дата обращения: 02.05.2020)

Дойль А.К. Глория Скотт / пер. Г. Любимова. Тула: Приокское кн. изд-во, 1990. C. 375-394. URL: http://lib.ru/AKONANDOJL/sh_glori.txt (дата обращения: 02.05.2020).

Дмитриева Л.П. Рецепция новеллы Э.А. По «Золотой жук» в России XIX в. // Вестник Томского государственного университета. 2010. №336. С. 7-10.

Доронина А. В., Белянина Е. В., Кандакова Н. А., Курчакова Л. Ю. Особенности перевода криптографических текстов с английского языка на немецкий и русский языки на примере рассказа Артура Конан Дойла «Пляшущие человечки» // Юный ученый. 2020. № 1 (31). $\quad$ C. 14-19. URL: https://moluch.ru/young/archive/31/1810/ (дата обращения: 02.05.2020).

Жеребило Т. В. Словарь лингвистических терминов. Назрань: Издательство OOO «Пилигрим», 2010 URL: https://rus-lingvistics-dict.slovaronline.com/ (дата обращения: 12.12.2020).

Кристи А. Цветы смерти / пер. А. Шаров, В Постников // Таинственное происшествие в Стайлз. Красноярск, 1990. С. 441-453.

Кристи А. Четверо подозреваемых /пер. И. Борисов // Большая четверка. Загадочный мистер Кин. Тринадцать загадочных случаев. М.: Артикул-принт, 2000. C. 567-581.

Кристи А. Четверо подозреваемых / пер. В. Ноздрина // Украденный миллион. Собрание сочинений в 4 томах. Том 2. Минск: Эридан, 1992. С. 328-342.

Кристи А. Четверо подозреваемых / пер. В. Кузьмичев // Избранные произведения. Том 28. Новосибирск: Гермес, 1996. С. 427-444.

Кристи А. Четверо подозреваемых / пер. В. Николаев // Романы. Рассказы. М.: Волюр, 1991. С. 332-345.
Кристи А. Четверо под подозрением. / пер. Л. Девель, В. Потенко. Новосибирск, 1990. С. 457-471.

Кристи А. Подозреваются все / пер. В. Тимашев // Избранное. Том 2. авторский сборник. Свердловск: Лига, 1991. С. 317-331.

Кристи А. Четверо подозреваемых / пер. В Михалюк // Английский детектив. Лучшее / Составитель: Энн Перри. Харьков: Книжный клуб «Клуб семейного досуга», 2012. С. 540-558.

Кристи А. Четверо подозреваемых / пер. 3. Красневская, 2016. URL: http://zviazda.by/be/news/20160623/1466679 431-agata-kristi-chetvero-podozrevaemyhtomas-uolsh-smertnyy-prigovor (дата обращения: 02.06.2020).

По Э. А. Золотой жук / пер. А. Старцев. М.: Детская литература, 1967. C. 7-43.

URL: http://poe.velchel.ru/?cnt=7\&tale $=$ a2 $\&$ page $=1$ (дата обращения: 02.05.2020).

По Э. А. Золотой жук / пер. К.Д. Бальмонт. СПб.: К Кристалл, 2002. C. 151-209. URL: http://az.lib.ru/p/po_e_a/text_1847_the_goldbug-balmont.shtml (дата обращения: 02.05.2020).

По Э. А. Золотой жук / пер. И.Д. Городецкий / Москва: Народная библиотека, $1883.56 \mathrm{c}$.

По Э. А. Золотой жук (сокр.) / пер. Н.В. Щелгунов // Дело. 1874. № 4. C. 309-320.

URL: https://ru.wikisource.org/wiki/Золотой_жук_ (По; Шелгунов) (дата обращения: 02.05.2020).

По Э. А. Золотой жук / анон. пер. Санкт-Петербург. Издание А. Смирдина (сына) и комп. $1858 . \quad$ URL: https://ru.wikisource.org/wiki/Золотой_жук_ (По;_Смирдин) (дата обращения: 02.05.2020).

По Э. А. Золотой жук // Журнал для чтения воспитанникам Военно-Учебных Заведений. 1848. Том LXXIV. № 295. С.231-257. № 296 С. 346-371. СанктПетербург. В типографии Военно- 
Учебных

Заведений.

URL:

https://ru.wikisource.org/wiki/Золотой_жук_ (По; Журнал для чтения) _ _ (дата обращения: $02.05 . \overline{2} 020$ ).

Культурные трансферы: проблемы кодов: коллект. монография / Центнер А.С., Хоцкина О.В., Ивлева М.А., Клейман Б.М., Проскурина А.В. Новосибирск: РИЦ НГУ, 2015. 224 c.

Brown D. The Da Vinci Code. New York: Anchor books, 2003. 597 p. URL: https://davincicode.bib.bz/ (Дата обращения: 02.05.2020).

Christie A. The Four Suspects. UK: Harper Collins, 2016. 40 p. URL: https://www.rulit.me/books/the-thirteen-

problems-read-291003-25.html (дата обращения: 02.06.2020).

Dean H. J., Boyd R. L. Deep into that darkness peering: A computational analysis of the role of depression in Edgar Allan Poe's life and death // Journal of Affective Disordersю 2020. Volume 266. Pp. 482-491.

Doyle A. C. The Adventure of The Dancing Men. USA: Dover, 1997. 80 p. URL: http://www.eastoftheweb.com/shortstories/UBooks/AdveDanc.shtml

(дата обращения: 02.05.2020).

Doyle A. C. The Gloria Scott. Kindle edition, 2020. 24 p. URL: https://eastoftheweb.com/shortstories/UBooks/GlorScot.shtml

(дата обращения: 02.05.2020).

Fariña-Pérez L.A. Joseph Bell (18371911): Centenary of the surgeon who inspired Arthur Conan Doyle for the character of Sherlock Holmes and who taught urology in Edinburgh // Actas Urológicas Españolas (English Edition). 2012. Volume 36, Issue 3. P. 202.

Giammarco E. Edgar Allan Poe: A psychological profile // Personality and Individual Differences. 2013. Volume 54, Issue 1. Pp. 3-6.

Gone, Maggie, gone. Season 20, Episode 13, 2009. URL: https://english-withfun.com/ru/tvshow/the_simpsons/season/20/episode/13 (Accessed 03.08.2021).
Llorente M., Hargrave R. Productive Aging and Creativity: The Lives and Arts of Agatha Christie, Frank Lloyd Wright and Wayne Wallace // The American Journal of Geriatric Psychiatrую 2021. Volume 29, Issue 4, Supplement. Pp. 4-5.

Poe E. A. The Gold-Bug. Boston: D. Estes \& company, 1899. 80 p. URL: https://publicdomainreview.org/collection/edg ar-allan-poes-the-gold-bug-

(Accessed 02.05.2020).

Raffensperger J. Was the real Sherlock Holmes a pediatric surgeon? // Journal of Pediatric Surgery. 2010. Volume 45, Issue 7. Pp. 1567-1570.

Vucinic D., Jovic N. Posttraumatic epilepsy in an Agatha Christie detective story // Epilepsy \& Behavior. 2010. Volume 17, Issue 4. P. 604.

\section{References}

Anagramma Voldemorta $v$ Ruskikh perevodakh [Voldemort's anagram in Russian translations] (2015). Available at: https://diary.ru/ d88/p204183439_anagramm a-voldemorta-v-russkih-perevodah.htm (Accessed 01 October 2020). (In Russian)

Brown, D. (2004). Kod da Vinchi [The Da Vinci Code], AST, Moscow, Russia, available at: https://www.litmir.me/br/?b=47079\&p=1

(Accessed 02 May 2020). (In Russian)

Doyle, A. C. (1981). Pliashushchie chelovechki [The Dancing Men], Mashinostroeniye, Moscow, Russia, available at: http://lib.ru/AKONANDOJL/sh_dancm.txt (Accessed 02 May 2020). (In Russian)

Doyle, A. C. (1990). Gloriia Skott [Gloria Scott], Priokskoye Publ., Tula, Russia, available at: http://lib.ru/AKONANDOJL/sh_glori.txt (Accessed 02 May 2020). (In Russian)

Dmitriyeva, L. P. (2010). Retseptsiia novelly E.A. Po «Zolotoi zhuk»v Rossii XIX v. [Reception of Edgar Poe's story The GoldBug in Russia in the 19th century], Tomsk State University Journal, 336, 7-10. (In Russian) 
Doronina, A. V., Belianina, E. V., Kandakova N. A. and Kurchakova, L. Yu. (2020). Peculiarities of translation of cryptographic texts from English into German and Russian on the example of the short story "The Dancing Men" by Arthur Conan Doyle], Iunyi uchenyi, 1 (31), 14-19. (In Russian)

Zherebilo, T. V. (2010). Slovar' lingvisticheskikh terminov [Dictionary of linguistic terms], Izdatelstvo «Piligrim», Nazran', Russia, available at: https://ruslingvistics-dict.slovaronline.com/ (Accessed 12 December 2020). (In Russian)

Christie, A. (1990). Tsvety smerti [The Flowers of Death], Tainstvennoe proisshestvie $v$ Stailz [The mysterious affair at Styles], Krasnoyarsk Publ., Krasnoyarsk, Russia, 441-453. (In Russian)

Christie, A. (2000). Chetvero podozrevaemykh [The Four Suspects], Bol'shaia chetverka. Zagadochnyi mister Kin. Trinadtsat' zagadochnykh sluchaev [The Thirteen Problems], Artikul-print, Moscow, Russia, 567-581. (In Russian)

Christie, A. (1992). Chetvero podozrevaemykh [The Four Suspects], Ukradennyi million. Sobranie sochinenii v 4 tomakh [Collected works in four volumes, vol. 2], Eridan, Minsk, Russia, 328-342. (In Russian)

Christie, A. (1996). Chetvero podozrevaemykh [The Four Suspects], Izbrannye proizvedeniia [Selected works, vol 28], Germes, Novosibirsk, Russia, 427-444. (In Russian)

Christie, A. (1991). Chetvero podozrevaemykh [The Four Suspects], Romany. Rasskazy [Novels. Stories], Volyur, Moscow, Russia, 332-345. (In Russian)

Christie, A. (1990). Chetvero pod podozreniem [The Four Suspects], Novosibirsk Publ., Novosibirsk, Russia, 457-471. (In Russian)

Christie, A. (1991). Podozrevaiutsia vse [Everyone is Suspected], Izbrannoe. Tom 2 [Selected works, Vol. 2], Liga, Sverdlovsk, Russia, 317-331. (In Russian)

Christie, A. (2012). Chetvero podozrevaemykh [The Four Suspects], Klub semeinogo dosuga, Kharkov, Ukraine, 540-558. (In Russian)

Christie, A. (2016). Chetvero podozrevaemykh [The Four Suspects], available at: http://zviazda.by/be/news/20160623/1466679 431-agata-kristi-chetvero-podozrevaemyhtomas-uolsh-smertnyy-prigovor (Accessed 02 May 2020). (In Russian)

Poe, E. A. (1967). Zolotoi zhuk [The Gold-Bug], Moscow, Russia, available at: http://poe.velchel.ru/?cnt=7\&tale=a2\&page $=1$ (Accessed 02 May 2020). (In Russian)

Poe, E. A. (2002). Zolotoi zhuk [The Gold-Bug], Krystall, St. Petersburg, Russia, available at: http://az.lib.ru/p/po_e_a/text_1847_the_goldbug-balmont.shtml (Accessed 02 May 2020). (In Russian)

Poe, E. A. (1883). A. Zolotoi zhuk [The Gold-Bug], Narodnaia biblioteka, Moscow, Russia. (In Russian)

Poe, E. A. (1874). Zolotoi zhuk [The Gold-Bug], Delo, 4, 309-320. (In Russian)

Poe, E. A. (1858). Zolotoi zhuk [The Gold-Bug], A. Smirdin (son) and comp., St. Petersburg, Russia. (In Russian)

Poe, E. A. (1848). Zolotoi zhuk [The Gold-Bug], Zhurnal dlya chteniia vospitannikam Voenno-Uchebnykh Zavedenii, v tipografii Voenno-Uchebnykh Zavedenii, St. Petersburg, Russia, 346-371. (In Russian)

Centner, A.S., Hockina, O.V., Ivleva, M.A., Klejman, B.M. and Proskurina, A.V. (2015). Kul'turnye transfery: problemy kodov [Cultural transfers: problems of codes], RIC NGU Novosibirsk, Russia. (In English)

Brown, D. (2003). The Da Vinci Code. Anchor books, New York, US. Available at: https://davincicode.bib.bz/ (Accessed 02 May 2020). (In English)

Christie, A. (2016). The Four Suspects. Harper Collins, UK. Available at: https://www.rulit.me/books/the-thirteenproblems-read-291003-25.html (Accessed 02 June 2020). (In English)

Dean, H. J. and Boyd, R. L. (2020). Deep into that darkness peering: A computational analysis of the role of 
depression in Edgar Allan Poe's life and death, Journal of Affective Disorders, 266, 482-491. (In English)

Doyle, A. C. (1997). The Adventure Of The Dancing Men, Dover, US. Available at: http://www.eastoftheweb.com/shortstories/UBooks/AdveDanc.shtml (Accessed 02 May 2020). (In English)

Kindle

Doyle, A. C. (2020). The Gloria Scott.

https://eastoftheweb.com/short-

stories/UBooks/GlorScot.shtml (Accessed 02 May 2020). (In English)

Fariña-Pérez, L.A. (2012). Joseph Bell (1837-1911): Centenary of the surgeon who inspired Arthur Conan Doyle for the character of Sherlock Holmes and who taught urology in Edinburgh, Actas Urológicas Españolas (English Edition), 36 (3), 202. (In English)

Giammarco, E. (2013). Edgar Allan Poe: A psychological profile, Personality and Individual Differences, 54 (1), 3-6.v (In English)

Gone, Maggie, gone (2009). Season 20, Episode 13. Available at: https://english-withfun.com/ru/tv-

show/the_simpsons/season/20/episode/13

(Accessed 03 August 2021). (In English)

Llorente, M. and Hargrave, R. (2021).

Productive Aging and Creativity: The Lives and Arts of Agatha Christie, Frank Lloyd
Wright and Wayne Wallace, The American Journal of Geriatric Psychiatry, 29 (4), Supplement, 4-5. (In English)

Poe, E. A. (1899). The Gold-Bug. D. Estes \& company, Boston, US. (In English)

Raffensperger, J. (2010). Was the real Sherlock Holmes a pediatric surgeon? Journal of Pediatric Surgery, 45 (7), 1567-1570. (In English)

Vucinic, D. and Jovic, N. (2010). Posttraumatic epilepsy in an Agatha Christie detective story, Epilepsy \& Behavior, 17 (4), 604. (In English)

\section{Конфликты интересов: у автора нет конфликта интересов для декларации. \\ Conflicts of Interest: the author has no conflict of interest to declare.}

Стрельцов Алексей Александрович, кандидат педагогических наук, доцент кафедры перевода и ИТЛ, Институт филологии, журналистики и МКК, Южный федеральный университет.

Alexis A. Streltsov, $\mathrm{PhD}$ in Pedagogics, Associate Professor, Department of Translation and IT in Linguistics, Institute of Philology, Journalism, and Intercultural Communication, Southern Federal University. 